\title{
Association between personal exposure to volatile organic compounds and asthma among US adult population
}

\author{
Ahmed A. Arif $\cdot$ Syed M. Shah
}

Published online: 1 August 2007

(C) Springer-Verlag 2007

Erratum to: Int Arch Occup Environ Health (2007) 80:711-719

DOI 10.1007/s00420-007-0183-2

The prevalence of dermatitis in NHANES 1999-2000 sample is $11.7 \%$ instead of $79.6 \%$ as printed in Table 1 of the paper. The authors regret this error.

The online version of the original article can be found under doi:10.1007/s00420-007-0183-2.

\footnotetext{
A. A. Arif $(\bowtie)$

Division of Health Services Research,

Department of Family and Community Medicine,

Texas Tech University Health Sciences Center,

3601 4th St, STOP 8161, Lubbock, TX 79430, USA

e-mail: ahmed.arif@ttuhsc.edu

\section{S. M. Shah}

Department of Community Health and Epidemiology, Institute of Agriculture Rural Environmental Health,

University of Saskatchewan, College of Medicine,

Saskatoon, SK, Canada S7N-OW8

e-mail: syed.shah@usask.ca
} 